\title{
Research \\ Securing a Future: Cree Hunters' Resistance and Flexibility to Environmental Changes, Wemindji, James Bay
}

\author{
$\underline{\text { Jesse S. Sayles }}^{1,2}$ and Monica E. Mulrennan ${ }^{2}$
}

\begin{abstract}
Accounts of the adaptive responses of northern aboriginal peoples include examples of purposive modification and management of ecologically favorable areas to increase resource productivity. Practices include clearing of trees, burning of berry patches and construction of fish weirs. This paper examines the adaptive capacity of the northern aboriginal community of Wemindji, east coast James Bay, in relation to long term landscape changes induced by coastal uplift processes. Associated changes are noticeable within a human lifetime and include the infilling of bays, the merger of islands with the mainland, as well as shifts in vegetative and wildlife communities. In response, generations of Cree hunters have actively modified the landscape using a variety of practices that include the construction of mud dykes and the cutting of tuuhiikaan, which are corridors in the coastal forest, to retain and enhance desirable conditions for goose hunting. We provide an account of the history, construction, and design of these features as well as the motivations and social learning that inform them. We reveal a complex and underappreciated dynamic between human resistance and adaptation to environmental change. While landscape modifications are motivated by a desire to increase resource productivity and predictability, they also reflect an intergenerational commitment to the maintenance of established hunting places as important connections with the past. Our findings support a revised perspective on aboriginal human agency in northern landscape modification and an enhanced role for aboriginal communities in adaptive planning for environmental change.
\end{abstract}

Key Words: adaptation; Cree; environmental change; flexibility; indigenous resource use; goose hunting; James Bay; landscape modification; resilience; resistance

\section{INTRODUCTION}

Environmental variability is a defining feature of northern ecosystems (Overpeck et al. 1997, ACIA 2005). As a result, the survival and persistence of northern aboriginal people has required the development of distinctive life ways capable of accommodating and responding to change (Balikci 1968, Langdon 1995, Turner and Clifton 2009). Numerous studies attest to the detailed place-based knowledge and beliefs of these long-term residents (Reidlinger and Berkes 2001, Nickels et al. 2002, Adger et al. 2003, Ford and Smit 2004) and to the importance of mobility and flexibility in their adaptive response (Steegman et al. 1983, Freeman 1996, Berkes and Jolly 2001).

For many aboriginal groups, enhanced resilience or adaptive capacity are often linked with habitat and natural resource diversity (Berkes and Folke 1994, Berkes and Davidson-Hunt 2006) which, according to Turner et al. (2003:442), "is often found to be at its greatest in ecological and cultural edge situations". Evidence from several sites within Canada (Anderson 1996, Peacock and Turner 2000, Turner and Peacock 2005) indicates that aboriginal peoples not only sought out and settled these ecologically favorable sites, but intentionally modified them to maintain and enhance the benefits they provided in terms of "livelihood flexibility and social-ecological resilience" (Turner et al. 2003:451). Practices involved in purposively managing these edges include clearing of trees and brush to increase edge habitat for berry growth (Turner 1999, Turner et al. 2003, Parlee et al. 2005), pruning and burning of berry patches to maintain their productivity (Turner 1999, Peacock and Turner 2000) and support small scale cultivation

${ }^{1}$ School of Geographical Sciences and Urban Planning, Arizona State University, Tempe, ${ }^{2}$ Department of Geography, Planning and Environment, Concordia University, Montreal 
(Davidson-Hunt 2003), burning of river margins and low areas of the boreal forest to enhance habitat conditions for ungulates (Lewis and Ferguson 1988), mounding of soils and construction of rock walls to expand the areas of tidal marshes suitable for wild root vegetable production (Deur 2000) and construction of fish weirs (Stewart 1977, Rogers 1983). Most of these practices are succession management systems (Davidson-Hunt 2003) that represent distinctive cultural adaptations to local biophysical and ecological settings, as recently underscored by Natcher et al. (2007) in relation to fire use among Athabaskan groups.

With increasing evidence that the effects of global climate changes "will be felt earlier and more keenly" (Berkes and Jolly 2001) in northern latitudes, how northern aboriginal communities respond to change has in recent years become a focus for northern studies (Berkes and Folke 1998, Krupnik and Jolly 2002, Hassol 2004, Huntington and Fox 2005, Ford et al. 2006, 2008, Pearce et al. 2006, Armitage et al. 2007). The concept of resilience, as defined with respect to the ability to withstand shocks and perturbations, the capacity for self-organization, and the capacity to learn and adapt (Resilience Alliance 2001), is widely applied in these assessments of change (Peacock and Turner 2000, Turner et al. 2000, Turner et al. 2003, Parlee et al. 2005, Berkes and Davidson-Hunt 2006, Natcher et al.2007). Documented responses include a range of strategies from adjustments in how, where and what people harvest (Peacock 1998, Ames 2005), to sharing through social networks and intercommunity trade (Berkes and Jolly 2001), to new institutions, such as co-management arrangements, that help facilitate self-organization and the capacity for learning (Berkes and Jolly 2001).

Unfortunately approaches aimed at improving resilience in the North too often focus on the provision of financial, technological, and institutional support (Nickels et al. 2002). Interventions from external sources, while much needed, could have unexpected negative consequences unless channeled in support of local approaches to responding and adapting to environmental change. Projects that build upon established customary institutions of land and wildlife management, and the adaptive strategies they support, may be more appropriate to, and sustainable within, local socialecological settings. Indeed Turner and Clifton (2009:181) suggest that many aboriginal peoples, because of their long history of involvement with constantly changing environments, "are likely to have the most robust strategies for facing unusual circumstances, and in the event that these occur, are less likely to be taken by surprise than those used to constancy and predictability in their lives".

In this paper we provide an account of socialecological resilience practices of Wemindji Cree people on the east coast of James Bay, northern Quebec, specifically the strategies used to create, maintain and enhance the highly dynamic and productive range of ecosystems they inhabit. While the regional significance of the James Bay coast as both an ecological and cultural edge has been recognized (Turner et al. 2003), with the exception of brief acknowledgements that dyke building, shrub clearing and forest corridor cutting have been practiced (Scott 1983, Reed 1991, Forest 2006, Peloquin and Berkes 2009), no comprehensive account is available of how local Cree communities have manipulated or maintained these edges. To develop such an account and contribute to growing understandings of aboriginal landscape modification we take both an actor-based and system-based analysis (Nelson et al. 2007) by focusing on what motivates individual Wemindji Cree hunters in management decision-making while also examining Cree landscape management from a system's perspective. We ask: (1) What landscape modifications have Wemindji Cree hunters made and what form do they take? (2) What motivates Cree to construct landscape modifications? (3) How are these modifications, and associated harvesting practices, intended to function in the context of environmental change? We focus in particular on the construction and function of two major modification practices associated with coastal goose hunting: dyke building and the cutting of corridors, known as tuuhiikaan (-an is singular, aan is plural), through the coastal forest.

Our case is instructive in several respects. Firstly, it provides a previously undocumented example from James Bay of purposive maintenance of ecological edges with respect to landscape modifications and enhancements, modes of selforganization, and social learning. Secondly, it documents how local knowledge and cultural connections to past practices and places are negotiated within the context of contemporary realities of change, with important implications for resilience. While the importance of local knowledge and flexibility for resilience in northern native communities has been acknowledged, the degree to 
which commitments to place and connections to the past are negotiated for achieving or maintaining resilience has not been recognized. Thirdly, our case demonstrates that aboriginal peoples, such as the James Bay Cree, with an extended history of landscape change, recognize and respond to change as an ongoing and inevitable phenomenon, and are well positioned to contribute to policy discussions and decisions concerning environmental and resource management as well as appropriate responses to climate change.

\section{STUDY AREA}

Wemindji is a Cree First Nations community located on the east coast of James Bay, northern Quebec. The Wemindji territory is bounded by latitudes $52^{\circ} 30^{\prime} \mathrm{N}$ and $53^{\circ} 10^{\prime} \mathrm{N}$, and extends about 300 kilometers inland (Fig. 1). The community is comprised of about 1,300 people (Cree Nation of Wemindji 2006) who are engaged in a mixed economy incorporating formal wage-labor, income subsidies, and subsistence harvesting (Scott 1988, 1996). While many families work as full-time hunters/fishers/trappers, others partake in so-called bush activities on weekends and holidays or after the wage-labor day is done. Others receive bush food through a culture of sharing and gift giving (Scott 1988, 1996).

Along James Bay, salt marshes develop in low energy coastal environments while boulders and cobbles, fringed with vegetation, are found in high energy settings. The most common marsh plants include Carex spp., Hippuris spp., Eleocharis spp., and Triglochin spp (Dignard et al. 1991). Willows (Salix spp.) also grow along many rivers and within the marsh-forest fringe (Dignard et al. 1991). Lichens, heaths (dominated by lichens and/or ericaceous shrubs), and white spruce forests (Picia glauca) characterize the mainland and interior of many islands (Dignard et al. 1991). The dense white spruce forest on the coast, as opposed to the black spruce ( $P$. mariana) inland, results in part from the thick marine fog that frequently blankets the area (Reed et al. 1996).

Eastern James Bay is undergoing coastal land emergence of around one meter per century as a result of isostatic rebound of land that was depressed by the enormous weight of ice sheets during the last glacial period (Andrews 1970, Hillaire-Marcel 1980, Begin et al. 1993, Lajeunesse and Allard
2003). As new terrestrial surfaces are exposed, upland vegetation (Salix bushes, for example) invades seaward at a roughly equivalent rate (van Moris and Begin 1993). Given the relatively low gradient (slopes of $1^{\circ}$ to $2^{\circ}$ ) of this emerged coastal plain (Dionne 1980), isostatic uplift renders this coastal environment among the most dynamic in the world, with channels closing up, islands attaching to the mainland, and new islands emerging within a person's lifetime (Sayles 2008). Thus, land emergence functions as a disturbance event that contributes to the diversity and productivity of this coastal setting (Davidson-Hunt and Berkes 2001).

Numerous multifamily hunting territories constitute the basic land and sea tenure unit of the James Bay Cree (Scott 1988). There are seven coastal territories within the Wemindji territory (Fig. 1), each of which encompasses a complex of coastal bays, estuaries and offshore islands which include an array of suitable hunting locations. Each hunting territory is under the stewardship of a senior hunting boss or tallyman, who is given responsibility for ensuring the productivity and sustainability of the land (Scott 1986). Under the guidance of the tallyman, a nonhierarchical system of resource management has evolved based on respect, reciprocity and sharing (Scott 1986). Within this system, Cree hunters are said to view themselves as part of a larger ecological "community-of-beings" (Berkes 1995:107).

Coastal activities include waterfowl hunting and fishing, as well as small game hunting, berry picking, egg and water collecting, and the gathering of firewood. Hunting of migrating geese is the major harvesting activity requiring an elaborate system of social coordination that includes rotational strategies of hunting to ensure optimal harvests while reducing goose population disturbance (Scott 1986). Geese stage in Wemindji during spring and fall migrations (Reed et al. 1996). Although the total populations of both the Lesser Snow Goose (Anser caerulescens caerulescens) and Canada Goose (Branta Canadensis) have experienced dramatic increases in recent years (Hass 2002, Abraham et al. 2005, CWS 2005, Harvey and Rodrigue 2007), Cree hunters have experienced a sharp downturn in their goose hunt over the same period (CRA 2005). Changes in goose behavior and migration patterns, related to a combination of biophysical and sociocultural factors, provide the most plausible explanation for these changes (Peloquin and Berkes 2009). 
Fig. 1. Location map of the Wemindji coastal hunting territories plus regional inset.

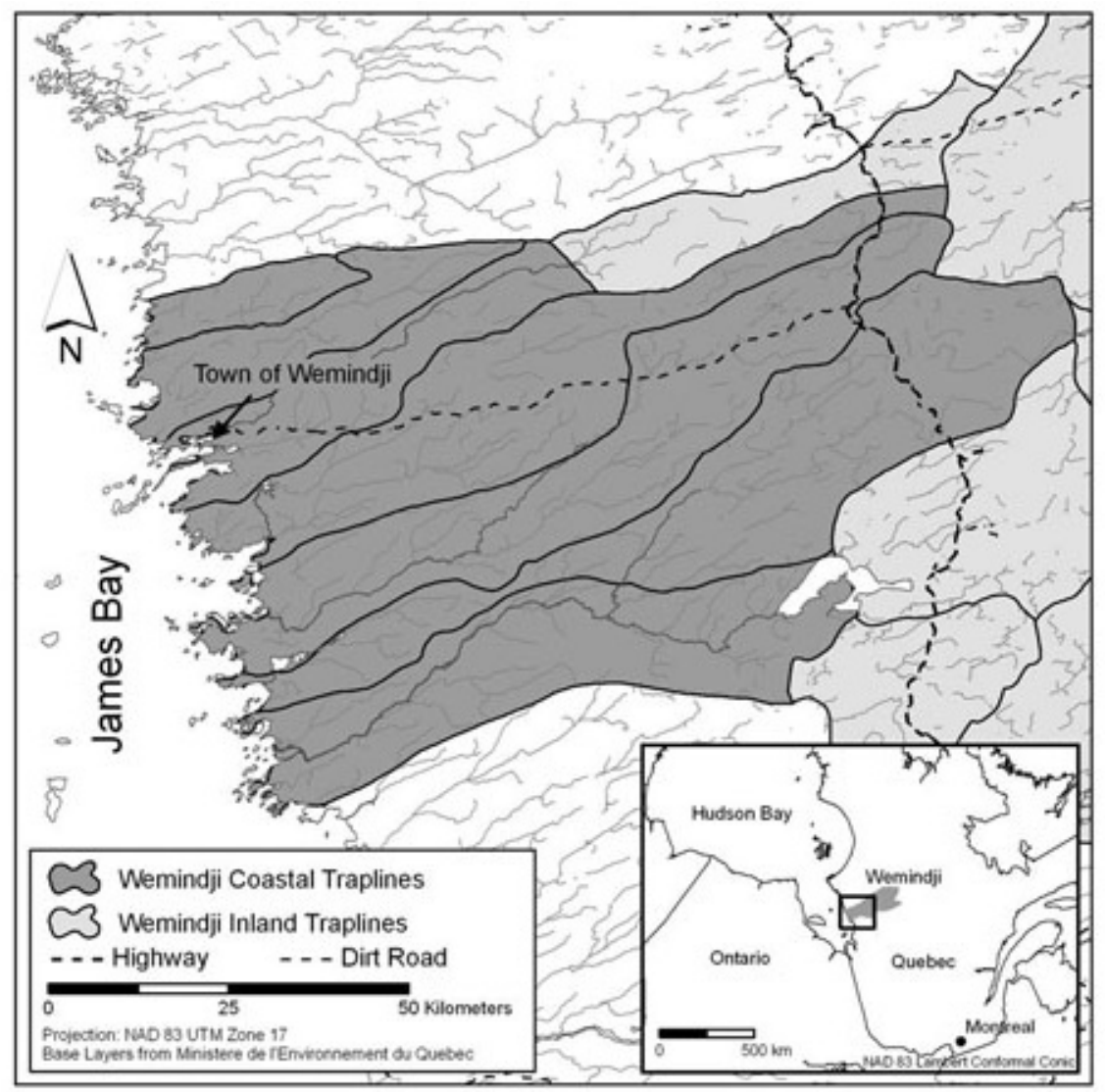

Geese feed in high marsh wetland areas during spring and in low marsh areas during fall, with bulbs and rhizomes as the major diet constituents (Reed et al. 1996). By grazing on the low marsh, geese maintain an attractive feeding area and suppress the establishment of coarser, less palatable high marsh vegetation (Hik et al. 1992). If maintained, this negative feedback can last from ten to fifty years, but if broken the expanded low marsh succeeds to high marsh in as little as two to five years (Hik et al. 1992, Handa et al. 2002).

As long-term inhabitants of this dynamic ecological edge, Cree hunters have learned to respond to environmental change by modifying local ecosystems and adjusting their harvesting practices as a means of maintaining or enhancing the productivity of the area and the predictability of their resource harvesting.

\section{METHODS}

We combined various methods to gain multiple insights about Cree land and resource use in the context of environmental change. We complemented an ethnographic-based methodology involving semi- and unstructured interviews with key informants and participant observations, with field surveys and remote image measurements and interpretations. Ethnographic work provided us with detailed accounts of where, how and, why Cree modify the landscape for resource harvesting. Ethnographic methods were also our primary vehicle for understanding environmental/ecological change over time. Field surveys and remote interpretations provided context and perspective on the location and extent of Cree's modification practices and revealed larger spatial-temporal patterns. The research involved seventeen weeks of field work over a two year period and was part of a larger collaborative interdisciplinary research team 
project involving a partnership of university researchers with local and regional Cree entities as well as provincial and federal government agencies (see http://www.wemindjiprotectedarea.org).

We worked with fifteen key informants, including seven coastal tallymen as well as other senior men and women and the director of the local Cree Trappers Association (CTA) who is also a senior hunter. Informants were considered experts by the community and were selected purposefully and/or through referral by other informants. More formal interviews were conducted in people's homes in town or in bush camps with less structured interviews arising spontaneously during participant observation. Spatial data were recorded on 1:50,000 or 1:30,000 topographic maps (formal interviews), or with a Garmin e-trex GPS (less formal interviews). Interviews and field surveys focused on: (1) locating and describing dykes and tuuhiikaan sites on each coastal hunting territory, (2) documenting the approximate date of their construction and the length of time particular modification practices have been in use (reported by decade, with reference to major life events, or when very old, in relation to past generations) as well as identifying changes and continuity in those practices over time, and (3) documenting the motivation behind particular modifications, as well as their function in resource harvesting and management in the context of environmental change.

Eight of ten dykes visited and nineteen tuuhiikaan were measured in the field using the GPS and/or a measuring tape. Ecological and geomorphic descriptions were also recorded for each site. Satellite imagery (2006, one meter panchromatic IKONOS; 2007, ten meter panchromatic SPOT; and 2001, fifteen meter panchromatic Landsat) and air photo imagery (1958/59) were interpreted using Arc GIS 9.2 to verify field measurements as well as to measure an additional six tuuhiikaan and evaluate the landscape context of all dyke and tuuhiikan sites.

\section{RESULTS}

Our findings indicate that Wemindji Cree have a long history of modifying the coastal landscape of eastern James Bay. Stone fish weirs, for example, were created generations ago, "before the white man came," "before there were nets," or during an elder's "grandfather's time." These bowl-shaped stone structures created a pool in which fish aggregated and were harvested by hand or spear. The practice continued into the early 1900 s by a few fishers, if only as an addition to gill net fishing. Another historic practice, described only in general terms by a couple of informants, was digging up marshes with shovels to make them more attractive to geese. Fire was also used in a limited capacity, mostly in smallscale experiments to improve the grasses geese feed on, to promote the growth of berries, and to clean up around camps. Several elders expressed reservations about fire management and emphasized the importance of not interfering too much. We "just let nature do the work," stated one elder woman (personal communication). "Willows would grow over where the berries were," said Anne Shashaweskum, another elder woman ". There is not much [we] could do, so [we] would just go to another place." (personal communication).

Among the most important landscape modifications practiced by Wemindji Cree however, both in terms of land area affected and human investment, are the construction of dykes and the cutting of tuuhiikaan. Both are concerned with the maintenance or enhancement of preferred goose hunting areas and both have a historical legacy and contemporary reality that manifests as a form of resistance to coastal change.

\section{Resistance to change}

The construction of dykes dates back beyond living memory. On several hunting territories, Cree spoke of dykes built as early as the 1600s. Dykes are constructed of logs, rocks and sod dug up in the marsh and range in width from four to 269 meters and in height from six to 30 centimeters (Table 1, Fig. 2). Dyke construction has been carried out on all seven coastal territories in recent decades, illustrating the continuity and widespread application of this management practice.

In early spring, when geese first arrive, James Bay is still covered with snow and ice. Pools in the high marsh are the first places to thaw and geese land in these to feed. The construction of dykes across these pools helps to maintain and/or enhance wetland areas that would otherwise dry out under conditions of coastal emergence, a process referred to by Cree as "land growth". As explained by elder Sam Hughboy, "maintaining the pond makes it so the land does not grow" (personal communication). The 
Table 1. Dyke lengths (meters), heights (centimeters), creation dates, and use status inventoried during interviews and/or field visits organized by hunting territory. Hunting territory or trapline codes have no relation to spatial distribution of traplines.

\begin{tabular}{|c|c|c|c|c|c|}
\hline & $\begin{array}{l}\text { Trap } \\
\text { line }\end{array}$ & $\begin{array}{c}\mathrm{L} \\
(\mathrm{m})\end{array}$ & $\begin{array}{l}\mathrm{H} \\
(\mathrm{cm})\end{array}$ & Date made & Still used? \\
\hline 1 & A & 269 & $6-9$ & Generations ago (1800 to 1900 s) & Yes \\
\hline 2 & A & 44 & $15-30$ & Generations ago & Yes \\
\hline 3 & A & - & - & Will build in fall 2007 & Yes \\
\hline 4 & A & - & - & No Data & Yes \\
\hline 5 & $\mathrm{~B}$ & 24 & 30 & 1988 or 1989 & Occasionally \\
\hline 6 & $\mathrm{~B}$ & 180 & $16-25$ & 1981 & Yes \\
\hline 7 & $\mathrm{~B}$ & - & - & 1988 or 1989 & Yes \\
\hline 8 & $\mathrm{~B}$ & - & - & Early to mid $1900 \mathrm{~s}$ & No \\
\hline 9 & $\mathrm{C}$ & 91 & $20-30$ & Early 1960s, youngest of 3 in marsh & Yes \\
\hline 10 & $\mathrm{C}$ & 87 & $10-20$ & Early $1960 \mathrm{~s}, 2^{\text {nd }}$ oldest of three in marsh & Yes \\
\hline 11 & $\mathrm{C}$ & - & - & Early 1960s, oldest of three in marsh & Yes \\
\hline 12 & $\mathrm{C}$ & - & - & 1940s & Yes \\
\hline 13 & $\mathrm{C}$ & - & - & Early 1900s & No \\
\hline 14 & $\mathrm{C}$ & - & - & No data & No data \\
\hline 15 & $\mathrm{D}$ & - & - & Late 1700 s, early 1800 s & No \\
\hline 16 & $\mathrm{D}$ & - & - & 2000 & Yes \\
\hline 17 & $\mathrm{D}$ & - & - & 2000 & Yes \\
\hline 18 & $\mathrm{E}$ & 24 & $15-30$ & 2001 or 2002 & Yes \\
\hline 19 & $\mathrm{E}$ & 4 & $15-30$ & Early to mid $1980 \mathrm{~s}$ & Yes \\
\hline 20 & $\mathrm{~F}$ & - & - & Grandfather's time (1940s - 1950s) & Yes \\
\hline 21 & $\mathrm{~F}$ & - & - & 1999 or 2000 & Yes \\
\hline 22 & G & - & - & Mid to late 1900 s; temporary & No \\
\hline
\end{tabular}


Fig. 2. A large dyke used for hunting geese. This dyke is 180 meters long and extends beyond the photo.

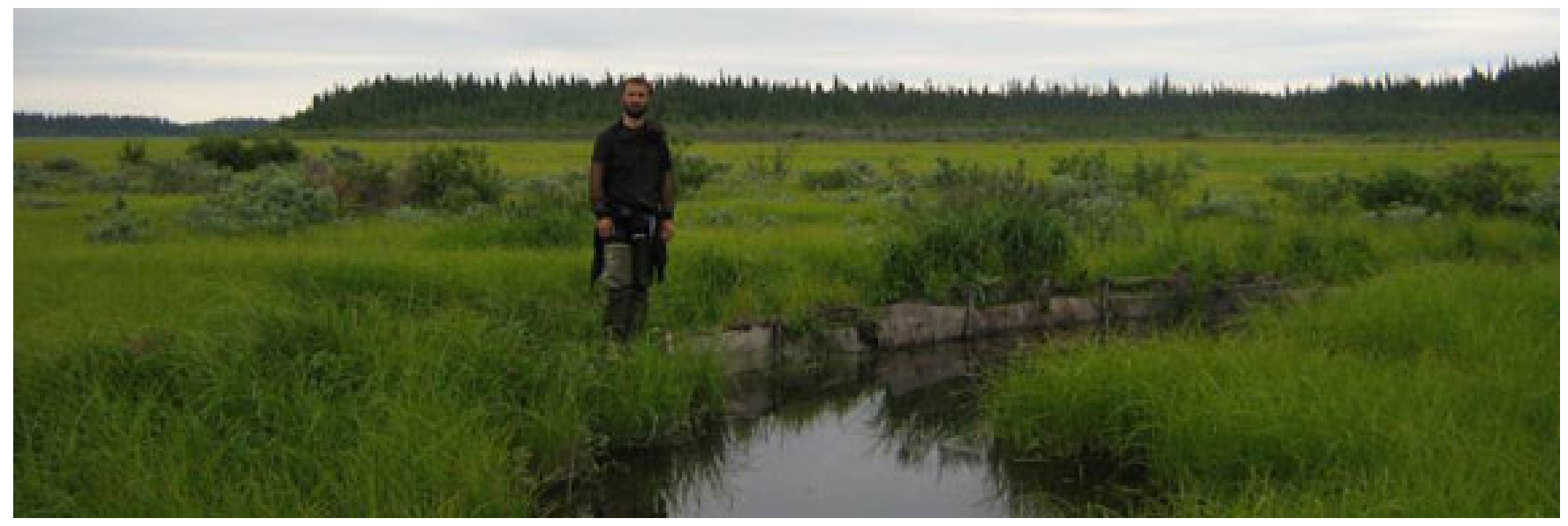

late Lot Kakabat, a former tallyman, expressed this in similar terms: "when you make a dyke for a pond, when you cut off ground from the earth, the earth would turn into mud; it was like it [land emergence] was all starting over again" (personal communication). Dyke creation serves to maintain desirable hunting areas by preventing the draining of coastal wetlands and the seaward invasion of high marsh plant species driven by land emergence.

Dykes function at three nested scales. At the smallest scale dykes maintain or enhance a wetland that is attractive to geese, both in terms of the impoundment created and the plant species supported. The latter include species and genera known to be palatable to geese, such as Carex paleacea, Hippuris tetraphylla, Eleocharis acicularis, and Triglochin palustris (Reed et al. 1996) in sharp contrast to species that dominate adjacent areas outside the pond. At a larger landscape scale dyke construction maintains important topographic and ecological conditions for goose harvesting. The spatial relationships between the dyke and the pond or impoundment it creates or maintains, the size and shape of the pond, and the proximity of hills, ridges, and shrub lines all affect how geese approach the pond and the ability of hunters to strategically position themselves for a successful hunt. Dykes are thus built with this larger spatial context in mind so that dyke construction is not just about impounding a specific wetland but ensuring the maintenance of a desirable hunting location. Finally, dyke construction is informed by the knowledge and experience Cree hunters have accumulated about geese in the region, particularly with respect to their migration paths and habitat preferences.

The maintenance of these hunting areas against the inevitable, ongoing forces of land emergence is driven by the subsistence and cultural significance of the goose hunt. With respect to the latter, dykes play an important role in maintaining links with the past as well as in providing for the future. When asked about the long-term prospects of a particular hunting location that has been actively maintained over the last half century by a set of dykes, Lot Kakabat explained: "The routine is going to keep going. People will keep hunting there, where people used to hunt; we might just upgrade it a bit I guess" (personal communication). Another tallyman, when asked why he was planning to build a new dyke in a specific bay, replied: "It will be a good spot for the young generations; they will have a place to hunt here" (personal communication). Thus, it is with an eye to both the past and the future that Cree hunters invest energy to create, maintain and enhance goose hunting sites.

Tuuhiikaan cutting started in the early 1900s with the most active cutting periods in the 1930s through to the 1960s and again from the 1980s to the mid-1990s. While some of the older tuuhiikaan are no longer in use, tuuhiikaan are being used and maintained on all seven coastal territories today 
(Fig. 3, Table 2). Tuuhiikaan are large features (Fig. 4, Fig. 5), ranging from 80 to 1,100 meters long and 30 to 270 meters wide (Table 3 ), and represent significant investments of time and energy for goose harvesting. They are located on headlands and ridges bordering the north side of coastal wetland complexes and tend to be oriented southeast to northwest, or south to north in accordance with goose flight paths (Table 2).

The purpose of the tuuhiikan is to enhance the predictability of certain goose hunting locations. Geese are known to fly low to the ground and pass through gaps in the coastal forest, thus the cutting of tuuhiikaan increases the predictability of intercepting these geese as they pass over a ridge; senior hunter Leslie Kakabat credits tuuhiikaan with an eighty percent success rate in terms of channeling geese (personal communication). On the few occasions that geese do not pass through, tuuhiikaan enhance the visibility of the approaching flock allowing hunters to reposition themselves and improve the chance of a successful hunt. Prior to the construction of these tuuhiikan, we were informed that hunters would position themselves on the ridge where they predicted an oncoming flock would pass. There was little the hunter could do however, if that flock passed elsewhere. By the time the hunter could see this, there was no opportunity for repositioning because the geese were too close.

Tuuhiikan cutting activity coincides with a period when geese shifted their migration route and were less available on the coast, as discussed above. According to 11 informants across the seven territories, Lesser Snow Geese started to decline from the coast in the 1950s and 1960s through to the 1980s at which point they were effectively gone from a resource harvesting perspective. Canada Geese have frequented the coast less since the 1980s and 1990s. Cree hunters may have been motivated to invest more energy cutting tuuhiikaan in the hopes of improving hunting success as geese disappeared from the coast. Tuuhiikan cutting may also have contributed to goose redistributions away from the coast, but our discussions with Cree hunters do not support this. Our informants always spoke of tuuhiikaan as facilitating hunting. Cree hunters are astute observers of local ecology (Scott 1996) and we do think that Cree would have recognized and responded adaptively had tuuhiikaan use negatively affected goose hunting. The extent to which increased numbers of hunters, along with numerous other variables (Peloquin and Berkes
2009) have contributed to the spatial redistribution of geese is unknown. Further study into the relationship between tuuhiikaan building and geese patterns is needed to further clarify these dynamics. Additional support that tuuhiikan cutting activity was motivated by redistributions of geese in the area is provided by statements made by elder Sam Hughboy. According to Sam, goose decoys were not needed in the period prior to tuuhiikaan cutting because: "there were so many geese you just needed to call them ...People knew where to hunt geese simply by looking at them" (personal communication). This comment suggests that geese were more plentiful and easier to harvest in the past with less incentive to use decoys and also one could infer less incentive to cut tuuhiikaan.

The establishment of a remedial works program in 1979 (SOTRAC 1980) may account for a spike in tuuhiikan cutting in the early 1980s. This program was part of an economic settlement package associated with regional hydroelectric development by the Quebec Government. The program aimed to offset some of the negative consequences to Cree natural resource use following hydro development and, among other provisions, included financial compensation for labor to build dykes and tuuhiikaan (SOTRAC 1980).

Similar to dykes, the tuuhiikan also serves to retard coastal succession. "Cutting [the] trees keeps it the same. If you don't cut them, they will grow back," explained Sam Hughboy (personal communication). Tuuhiikaan are cut on ridges that have long been used as goose hunting locations. As coastal land emerges and upland species invade seaward, trees become established on the ridges. Yet the coastal bays and wetland complexes south of these areas often remain important goose feeding areas. Thus, cutting tuuhiikaan extends the usefulness of established and familiar hunting sites, retaining an important cultural link with past generations of hunters in the context of a rapidly changing coastal landscape.

\section{Flexibility to change}

While Cree hunters expend significant efforts in retarding or resisting coastal emergence, resistance is just one approach within a broader strategy of response to ongoing coastal change. Cree recognize when larger temporal-spatial changes render their resistance impracticable. For example, a particular 
Fig. 3. Tuuhiikan cut dates displayed by hunting territory. X-error bars represent the range of date reporting. For example, a tuuhhikan cut in the early 1980s is centered at $1982.5 \pm 2.5$ yrs. A tuuhiikan cut in the 1980 s is centered on $1985+$ or $-5 y$ rs. $n=32(30+2)$. Cut dates were recorded for 30 tuuhiikaan, however, two tuuhiikaan were re-cut and increased and are represented as a second cut date in the Figure. The labels "Lesser Snow Goose decline" and "Canada goose decline" are situated to indicate the time periods at which these events were reported. Hunting territory or trapline codes have no relation to spatial distribution of traplines.

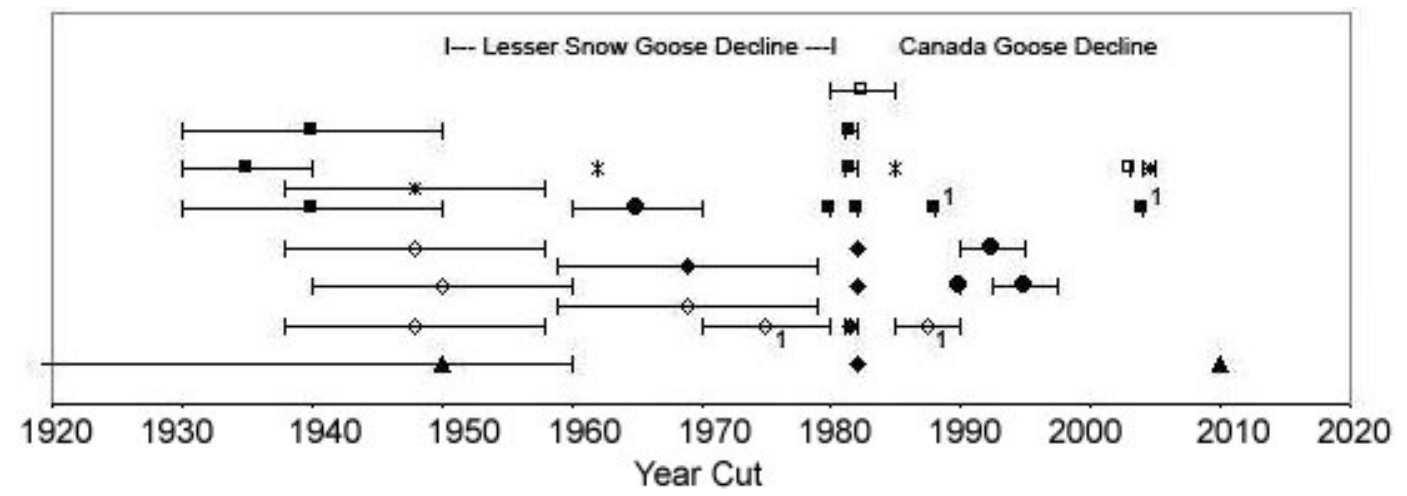

Pairs are indicated with a "1". ( $(\boldsymbol{\Delta}=\mathrm{A}, \bullet=\mathrm{B}, \bullet=\mathrm{C}, \boldsymbol{\bullet}=\mathrm{D}, \square=\mathrm{E}, \bullet=\mathrm{F}, *=\mathrm{G})$

coastal wetland subjected to emergence and plant invasion will eventually become so unattractive as a goose feeding area that continued dyke maintenance is futile. Or, the feeding grounds adjacent to a tuuhiikan may succeed to upland vegetation and create conditions that result in a shift in the flight path of geese such that the tuuhiikan loses its utility. In such cases, Cree abandon and then relocate their modification efforts.

Of the 22 dykes inventoried, four are no longer in use (Table 1). Larger scale changes have rendered these areas undesirable to geese and thus, poor hunting sites, which in turn prompted a resource management decision to abandon their use. Another example we encountered of this type of adaptive resource management involved deliberations between a tallyman and elders about whether to cease maintenance of a particular dyke, the utility of which was being undermined by changes in goose flight patterns. Thus, we witnessed and heard other reports of openness to relocation once a certain threshold of change has been reached. Notwithstanding this, the longevity of hunting sites, many of which extend back over several generations of hunters, indicates that the commitment to established sites is a powerful one.

Tuuhiikaan cutting over time reflects the dynamic between maintaining and shifting particular hunting sites in the context of ongoing coastal emergence. Figure 6 provides an example of an old tuuhiikan that was cut in the 1960s/1970s, subsequently abandoned, and then replaced by tuuhiikaan cut farther west. The old tuuhiikan was on a ridge long used as a hunting site. As the coast emerged, and shorelines retreated westward, the marsh seaward of the old tuuhiikan was invaded by upland species and became unattractive to geese. The dramatic rate of change over a fifty year interval is illustrated by a comparison of high resolution satellite and historic air photo imagery. According to our informants, a similar scenario occurred in a shallow bay just north of this location. A tuuhiikan first cut in the 1930s was abandoned in the 1980s and new tuuhiikaan were constructed to the west. Unfortunately high quality remote images are not available for this area so visual representation is not possible. Thus, 
Table 2. Selected tuuhiikan metrics for all inventoried tuuhiikaan. Many tuuhiikaan tend to be wider at one or both ends thus a minimum and maximum width was measured for each. $n=31$. Hunting territory or trapline codes have no relation to spatial distribution of traplines.

\begin{tabular}{|c|c|c|c|c|c|c|c|}
\hline Trapline & Angle & Cut date & Last maintenance & $\begin{array}{c}\text { Area } \\
\text { (ha) }\end{array}$ & $\begin{array}{l}\text { Width } \\
\text { (m) }\end{array}$ & $\begin{array}{l}\text { Length } \\
(\mathrm{m})\end{array}$ & $\begin{array}{c}\text { Still } \\
\text { used? }\end{array}$ \\
\hline A & $\mathrm{S}-\mathrm{N}$ & Time immemorial & Late 50 s, \& again in 2003 & 3.00 & 230 & 370 & Yes \\
\hline $\mathrm{A}$ & SE-NW & Will cut in next few years & $\mathrm{n} / \mathrm{a}$ & $\mathrm{n} / \mathrm{a}$ & $\mathrm{n} / \mathrm{a}$ & $\mathrm{n} / \mathrm{a}$ & $\mathrm{n} / \mathrm{a}$ \\
\hline $\mathrm{B}$ & SE-NW & $1981 / 1982$ & No data & 2.73 & 100 to 150 & 250 & Yes \\
\hline $\mathrm{B}$ & SE-NW & 1982 & $\begin{array}{l}\text { 2006, hadn't cleared for a } \\
\text { few years }\end{array}$ & 4.37 & 130 to 230 & 300 & Yes \\
\hline $\mathrm{B}$ & SE-NW & 1982 late spring & 2003 & 3.50 & 115 to 150 & 250 to 300 & Yes \\
\hline B & SE-NW & 1982 & $\begin{array}{l}\text { Informant did not } \\
\text { remember }\end{array}$ & 5.89 & 130 to 150 & 415 & Yes \\
\hline $\mathrm{B}$ & $\begin{array}{l}\text { S-N or } \\
\text { SE-NW }\end{array}$ & After 1958 , cut w/ axe & No data & No data & No data & No data & No \\
\hline $\mathrm{C}$ & SE-NW & 1990 & Never & 2.83 & 100 to 110 & 280 & Yes \\
\hline $\mathrm{C}$ & SE-NW & $1960 \mathrm{~s}$ & Never & 1.01 & 30 to 50 & 300 & No \\
\hline $\mathrm{C}$ & SE-NW & Mid 90s & $\begin{array}{l}\text { Never, but needs to be } \\
\text { done soon }\end{array}$ & 11.99 & 100 to 260 & 790 & Yes \\
\hline $\mathrm{C}$ & SE-NW & Early 90s & Never & 4.02 & 50 to 70 & 665 & Yes \\
\hline $\mathrm{D}$ & $\begin{array}{l}\text { SE- } \\
\text { NNW }\end{array}$ & 1980 & Never & 10.89 & 230 to 240 & 470 & Yes \\
\hline $\mathrm{D}$ & SE-NW & 1982 & 2004, extended $\mathrm{N}$ to lake & 6.17 & 90 to 200 & 430 & Yes \\
\hline $\mathrm{D}$ & SE-NW & $1930 \mathrm{~s}$ & $\begin{array}{c}\text { No data } \\
\text { Last used 1980s }\end{array}$ & No data & No data & No data & No \\
\hline $\mathrm{D}$ & S-NNE & 1988 & No data & 2.24 & $30-80$ & 450 & Yes \\
\hline $\mathrm{D}$ & No data & $1930 \mathrm{~s}, 40 \mathrm{~s}$ or $50 \mathrm{~s}$ & No data & 0.34 & 40 to 45 & 80 & No data \\
\hline $\mathrm{D}$ & SE-NW & 1981 or 1982 & No data & 2.03 & 60 to 110 & 260 & Yes \\
\hline $\mathrm{D}$ & No data & $1940 \mathrm{~s}$ & No data & $\mathrm{n} / \mathrm{a}$ & $\mathrm{n} / \mathrm{a}$ & $\mathrm{n} / \mathrm{a}$ & $\mathrm{n} / \mathrm{a} \dagger$ \\
\hline $\mathrm{D}$ & No data & 1979 & No data & $\mathrm{n} / \mathrm{a}$ & $\mathrm{n} / \mathrm{a}$ & $\mathrm{n} / \mathrm{a}$ & $\mathrm{n} / \mathrm{a} \dagger$ \\
\hline $\mathrm{E}$ & SE-N & Early $80 \mathrm{~s}$ & Informant was not sure & 1.10 & 70 to 100 & 150 & Yes \\
\hline $\mathrm{E}$ & SE-NW & 2003 & Never & 7.50 & 50 to 80 & 400 & Yes \\
\hline $\mathrm{F}$ & $\mathrm{S}-\mathrm{N}$ & Before 1958 & Around 2000 & 7.27 & 70 to 160 & 615 & Yes \\
\hline $\mathrm{F}$ & No data & Before 1958 & No data & No data & No data & No data & No \\
\hline $\mathrm{F}$ & $\mathrm{S}-\mathrm{N}$ & 1970s, was smaller & Late 1980 s, made bigger & 4.00 & 130 & 345 & Yes \\
\hline
\end{tabular}




\begin{tabular}{|c|c|c|c|c|c|c|c|}
\hline $\mathrm{F}$ & $\begin{array}{l}\text { SEE- } \\
\text { NWW }\end{array}$ & After 1958 & 2001 & 0.36 & 30 & 150 & Yes \\
\hline $\mathrm{F}$ & SE-NW & Grandfather's time & No data & 2.30 & 110 to 160 & 240 & Yes \\
\hline G & $\begin{array}{l}\text { SSE- } \\
\text { NNW }\end{array}$ & 1985 & No data & 3.88 & 150 to 200 & 220 & Yes \\
\hline G & SE-NW & No data & No data & 5.41 & 50 to 60 & 1,100 & No \\
\hline G & $\mathrm{S}-\mathrm{N}$ & 1962 & Never & 32.16 & 270 to 370 & 1,050 & No \\
\hline G & SE-NW & 2004 to 2005 & No data & 3.70 & 160 to 190 & 290 & Yes \\
\hline G & SE-NW & Before 1958 & Late $1990 \mathrm{~s}$ & 0.60 & 55 to 70 & 100 & Yes \\
\hline
\end{tabular}

$\dagger$ Area burnt in mid 1980s destroying tuuhiikan

temporal-spatial shifts in tuuhiikaan correlate with coastal land emergence and associated changes in goose flight paths. Indeed, we identified half a dozen abandoned tuuhiikaan in settings that were no longer regarded suitable for goose hunting (Table 2).

Beyond these ongoing changes associated with coastal uplift processes, the marked decline in recent decades in the number of geese visiting the coast has been linked, by our informants, to the presence of large inland water bodies associated with regional hydro-electric development projects (see Peloquin and Berkes 2009 for more details). More and more geese fly inland these days in preference to the coast. In response, an increasing number of Wemindji Cree have shifted their hunting efforts inland to sites along the $90 \mathrm{~km}$ access road (Fig. 1), and trails associated with it, that connects the village of Wemindji to the James Bay Highway (Peloquin and Berkes 2009). Interestingly, gravel pits along the road are now being used in much the same way that dykes are used on the coast.

Another recent response to the decline in the coastal goose hunt has been the launch of restoration projects in previously important goose feeding areas which have become dense high marsh, dominated by willows and upland grasses that are unpalatable to geese. According to our informants, reduced numbers of geese along the coast have accelerated the rate of coastal plant succession through a positive feedback relationship between the decreased foraging activity of geese and the establishment of coarser upland marsh vegetation. The restoration projects, which are experimental in approach, aim to make previously important coastal feeding areas attractive to geese again. According to Edward Georgekish, CTA Director, the initial approach is to cut back the willows and then use heavy machinery, such as a mechanized backhoe or plough, to remove the top layer of soil so the willows and grasses cannot reestablish (personal communication). If tallymen and senior hunters are satisfied with the results, the CTA hopes to expand these projects to other areas along the coast. This example, similar to those discussed above, illustrates how Cree resource management is conducted as a process of on-the-ground adaptive learning under the guidance of experienced and knowledgeable resource users. Interestingly, this particular initiative represents a revival of the historic practice, mentioned earlier, of digging up and overturning marshes by shovel although there is widespread consensus that this approach is only viable today if heavy machinery is available. The CTA is currently reviewing what environmental permits would be required to support this. Other strategies to enhance areas for goose hunting include experiments with corn feeding and fire burning. Thus, resource management decision making is informed by past practices, is open to availing of modern technologies, and is sometimes subject to external regulatory requirements as a result.

\section{DISCUSSION}

The inherent variability of the boreal forest combined with the highly dynamic nature of the eastern James Bay coastline presents particular challenges and opportunities for Cree hunters; floral 
Fig. 4. Two large tuuhiikaan. The left tuuhiikan is 115 to 150 meters wide and 250 to 300 meters long. The right tuuhiikan is 130 to 230 meters wide and 300 meters long. They were first cut in the early 1980s and were last maintained (re-cut) in 2003 and 2006, respectively.

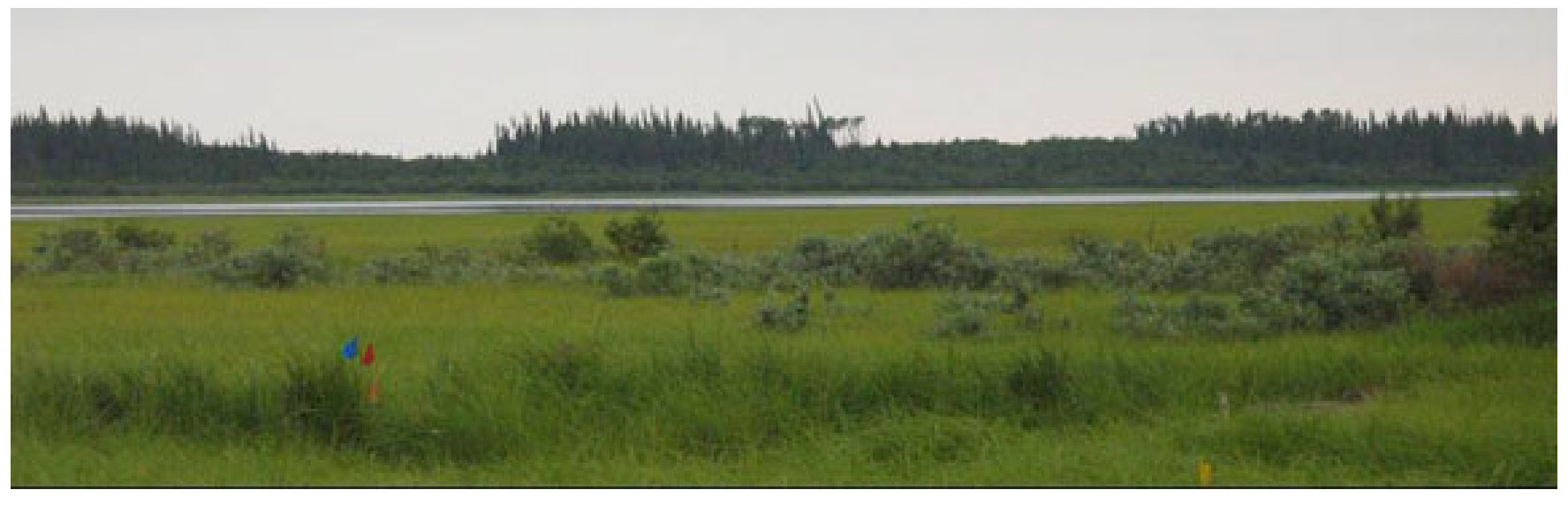

and faunal progressions can change dramatically from year to year and from one area to another at a given time (Steegman et al. 1983). The accumulated changes can be substantial during an individual hunter's lifetime. The desire to reduce resource unpredictability while maximizing the productivity of these areas is thus a core feature of the adaptive management response taken by Cree hunters.

The construction of dykes and tuuhiikaan contributes directly to increased resource predictability by increasing the chances of a successful goose hunt. Both features are designed and constructed to alter coastal ecology at the pond or landscape scale, that is, local bay and headland scale. At the individual pond scale, a dyke can suppress or delay wetland succession, thereby creating or maintaining an attractive habitat for waterfowl to feed and rest. Dykes also impact on the success of the hunt at a larger scale by influencing goose flight paths relative to the location of attractive ponds. The cutting of tuuhiikaan, similar to corn dispensing, burning, and restoration projects, also contributes to maintaining and/or enhancing the predictability of the resource, in this case, geese and other wildfowl species, in the context of ongoing shoreline and coastal habitat changes.

Beyond maintaining and/or enhancing resource predictability, dykes and tuuhiikaan prolong the usefulness of established hunting locations. The maintenance of an established hunting site with a proven track record that extends back through decades to previous generations of hunters supports this by providing continuity in the setting of a primary hunting activity. The elaborate system of social organization and learning required to ensure an optimal, sustainable goose hunt must take account of numerous internal and external factors, including changing environmental conditions, goose abundance, and hunting pressure. The familiarity of an established hunting place that is imbued with the knowledge, experience and memories of generations of past hunters can go a long way towards providing a stable base in a broader context of uncertainty and unpredictability. Thus, the construction of a dyke can extend the lifespan of a pond as a core feature of a hunting strategy designed to maximize the number of geese killed while minimizing disturbance to other geese. In a similar way the cutting and maintenance of tuuhiikaan extends the usefulness of established hunting sites by influencing the predictability of geese flight patterns.

Our examination of Cree landscape modifications is also instructive in demonstrating how harmonization of resistance and flexibility, as adaptive responses to change, creates socialecological resilience (Fig. 7). Crees oppose change; they retard wetland succession and coastal forest 
Fig. 5. A small tuuhiikan, 55 to 70 meters wide and 100 meters long. It was first cut before 1958 and was last maintained (re-cut) in the late 1990s.

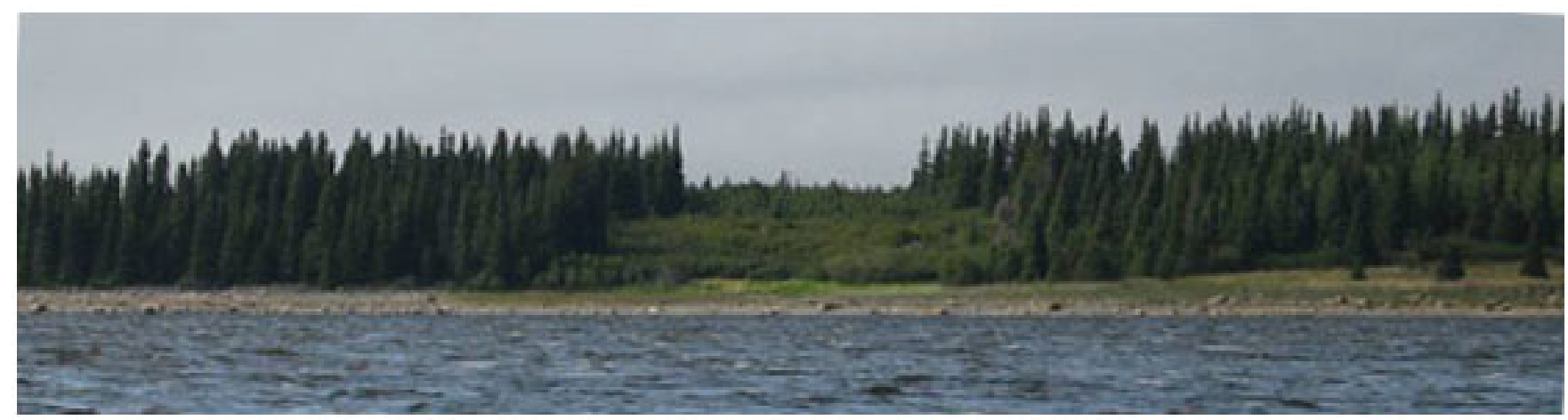

development. For them, there is security in the known and this opposition to change maintains continuity in harvesting locations over time. But change is inevitable and ongoing. Once a certain threshold of change is reached, Crees abandon existing modification sites and relocate to new ones, usually just seaward of the old sites although in recent years many hunters have relocated their hunting efforts inland and are experimenting with coastal restoration projects. Thus, the Cree response to change is one of harmonization. On the one hand they oppose predictable change and variability normal to the system, such as shoreline movement, subsequent habitat shifts, and uncertainty in goose behavior. On the other hand, they remain attuned to larger scale changes, such as spatial redistributions and availability of geese, regional land use changes, and climate change, and are willing to experiment and adapt. As such, this case demonstrates flexibility and responsiveness to various drivers and thresholds of change operating at a range of different interacting scales.

The impact of dykes and tuuhiikaan on the ecological integrity of the broader region was not addressed by our study. Both features are sufficiently large to be seen from satellite imagery. However, the limited length of the tuuhiikaan, which are usually less than $1 \mathrm{~km}$, is unlikely to result in landscape fragmentation and habitat alienation issues associated with transmission lines, roads and pipelines. Similarly, drainage alterations of coastal wetlands through the construction of dykes, while not insignificant at the local landscape scale, mimic natural processes and likely have an imperceptible impact in a broader regional context of a drainage system that has been significantly modified as a result of extensive dam building, river diversion and reservoir creation associated with the James Bay hydroelectric project. Notwithstanding this, population numbers and technology would have limited the extent and impact of these practices in the past. In the unlikely event that Crees would consider expanding the scale of these landscape modifications in the future, an assessment of the possible impact on the region, such as in terms of biodiversity or carbon budgets, would certainly be needed.

Cree landscape modifications provide irrefutable evidence that Crees have not only occupied and used their traditional lands but have been and continue to be active agents in managing and modifying the land and its resources. Furthermore the level of selforganization and social learning required to construct and subsequently maintain these features, particularly in a context of limited access to technology in past decades/centuries, has interesting implications for conventional descriptions of Cree as highly mobile hunters engaged in diffuse foraging. Notions of Crees as active human agents of landscape change run counter to the dominant narrative of the north as a pristine wilderness, untouched by human agency (Hulan 2003). This 
Table 3. Summary statistics for tuuhiikan dimensions. Minimum, maximum, average, and standard deviation are reported for width (meters), length (meters), and area (hectors). Many tuuhiikaan tend to be wider at one or both ends, thus a minimum and maximum width was measured for each. $\mathrm{n}=25$.

\begin{tabular}{lcccc}
\hline \hline & $\begin{array}{c}\text { Minimum } \\
\text { width (m) }\end{array}$ & $\begin{array}{c}\text { Maximum } \\
\text { width (m) }\end{array}$ & $\begin{array}{c}\text { Length } \\
(\mathrm{m})\end{array}$ & $\begin{array}{c}\text { Area } \\
\text { (ha) }\end{array}$ \\
\hline Minimum & 30.00 & 45.00 & 80.00 & 0.34 \\
Maximum & 270.00 & 370.00 & 1100.00 & 32.16 \\
Average & 120.60 & 149.80 & 399.80 & 5.17 \\
Std Dev & 65.10 & 78.00 & 264.03 & 6.37 \\
\hline
\end{tabular}

narrative, through the erasure or marginalization of aboriginal peoples has supported the expansion of state control under the guise of development and conservation programs (Sandlos 2007). The recently launched "Plan du Nord", of Quebec Premier Jean Charest, which hinges around "occupying the north" and the exploitation of "northern riches" (German 2009), was initially crafted with no input from northern aboriginal peoples suggesting that the legacy of the north as a hinterland for resource extraction, rather than a homeland for aboriginal peoples (Berger 1977) persists. Recognition of Crees as active and adaptive agents strengthens the case for northern aboriginal peoples to take a lead role in decisions concerning the environment and their future more generally.

Finally, aboriginal landscape modifications may have implications for environmental management approaches. While current scenarios for human adaptation to climate related changes are based on sea-level rise rather than coastal land emergence, the consideration and accommodation of multiple scales of ecological interaction in the design and construction of dykes and tuuhiikaan is instructive for planning approaches everywhere. Holistic planning that takes account of past experience and observation and that works with, rather than against, the functioning of nature underscores the value of low cost, soft engineering approaches as an adaptive strategy. For example, such approaches may offer temporary alternatives to expensive, highly disruptive relocation programs with the added benefit of recognizing and enhancing the capacity of northern communities to cope with change.

\section{CONCLUSION}

Several studies have shown how northern aboriginal peoples purposely modify and manage local ecosystems, particularly the more biodiverse and dynamic habitats associated with ecological edges, to increase the productivity of these sites and enhance social-ecological resilience. We strengthen this understanding through our exploration of the strategies used by Cree hunters to create, maintain and enhance desirable areas and conditions for goose hunting. The construction of dykes and cutting of tuuhiikaan represents a particular adaptation to living in a highly dynamic coastal setting in which the shoreline shifts and islands join the mainland within a person's lifetime. Cree observations and understanding of multiple scales of ecological relationships inform the location, design and function of these features through a process of adaptive management, which in turn is dependent on the ability of Cree hunters as members of a coastal hunting territory to self organize, learn from experience and innovate (Berkes and Folke 1998). While these landscape modifications are motivated by a desire to increase resource predictability and productivity, our case indicates that they also reflect an intergenerational commitment to the maintenance of established hunting places as familiar, culturally important sites imbued with meaning through their connections with the past. At the same time, Cree hunters are pragmatists, recognizing thresholds of change as cues for resistance to give way to acceptance of change. The balance or harmonization achieved in managing these dual imperatives is a hallmark of 
Fig. 6. Temporal-spatial shifts in tuuhiikaan. The top two scenes compare a 1959 air photo and 2006 Ikonos image. Below is a vector overlay presented at double the scale of digitized tree and shrub lines used as proxies for shoreline movement because tidal variation between the two scenes cannot be controlled for (Grey 1983). The overlay shows the rapid rate of shoreline movement. The south-eastern tuuhiikan was cut in the 1960s or 1970s. Landscape change rendered the area poor for hunting, so four new tuuhiikaan were cut to the north-west, on the point, in the 1980s. The 1959 air photo was scanned at 6000 dpi and georeferenced to the Ikonos image using boulders, buildings, and other stable features as pass points, with a total RMS error of $8.09276 \mathrm{~m}$ in Arc GIS 9.2. Digitizing was done at a 1:5,000 scale.

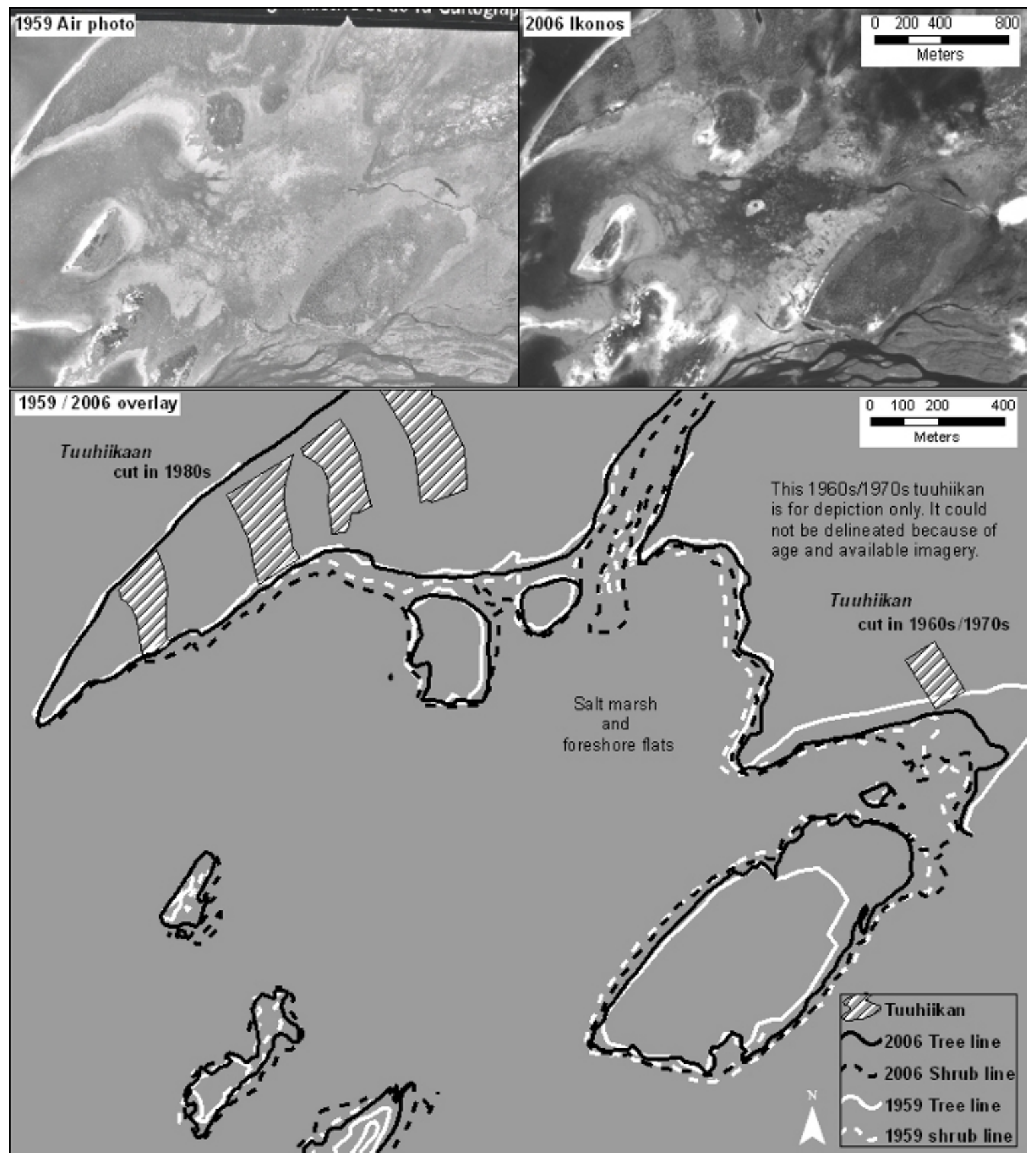


Fig. 7. Feedback diagram depicting resistance and flexibility in context of landscape modification for resource harvesting. Plus signs indicate a positive relationship, or a direct relationship of increase or decrease between one parameter and the parameters it influences. Negative signs indicate a negative relationship, or an opposite relationship of increase or decrease between one parameter and the parameters it influences. Solid arrows and dashed arrows represent two different temporal scales with the latter being larger. Dashed arrows and solid arrows do not create closed feedback loops because of their different scales.

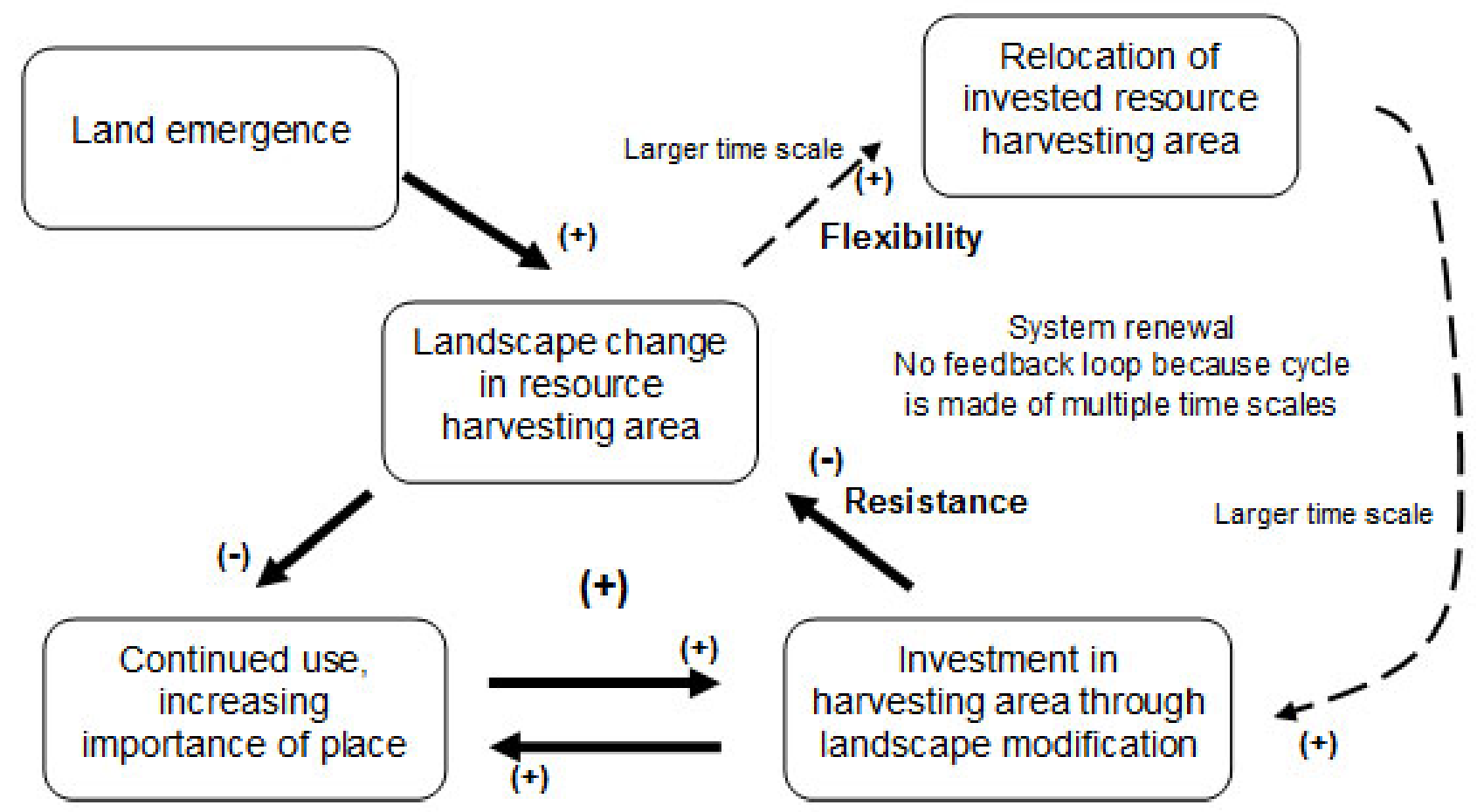

Cree adaptive strategies and of their resilience as a society.

Our study shows that members of the Cree community of Wemindji have not only occupied and used their traditional territory but have been active agents of landscape change. Recognizing these adaptive landscape modification practices confronts timeworn fallacies of the north as an unoccupied wilderness, supports the value of designing landscape modifications that respond to local ecological conditions, and highlights the potential capacity of northern aboriginal peoples to take a lead role in decisions concerning their future, particularly in the context of adaptations to climate change.
Responses to this article can be read online at: http://www.ecologyandsociety.org/vol15/iss4/art22/ responses/

\section{Acknowledgments:}

This research was conducted as part of the Wemindji Protected Area Project (http://www.wemindjiprotectedarea. org), funded by the Community-University Research Alliance (CURA) program and the Aboriginal Research program of Canada's Social Sciences and Humanities Research Council (SSHRC). We owe our gratitude to the Wemindji community, especially to Alan Matches, Andrew Atsynia, Anne Shashaweskum, Beverly Mayappo, Bill Stewart, Billy Gilpin, Clayton Matches, Daisy Atsynia Sr., Danny Tomatuk, Edward Georgekish, Erny 
Hughboy, Fred Asquabaneskum, Fred Stewart, George Kudlu, George Stewart, Henry Stewart, Irene Mistacheesick, Leonard Asquabaneskum, Leslie Kakabat, Lillian Atsynia, Lot Kakabat, Morris Tomatuk, Nancy Danyluk, Raymond Atsynia, Rita Atsynia, Rodney Mark, Sam Georgekish, Sam Hughboy, Sarah Tomatuk, Sinclair Mistacheesick, William Mistacheesick, and Winnie Asquabaneskum. Chiniskumitin skuutamaahaakaatuuwits iуiyuu iihtuun. Thank you also to colleagues in the Wemindji Protected Area Project and McGill's Computational Archaeology Lab for support and insights, and to Colin Scott, George Wenzel, Karina Benessaiah, and three anonymous reviewers for their comments and advice.

\section{LITERATURE CITED}

Abraham, K.F., R.L. Jefferies, and R.T. Alisaukas. 2005. The dynamics of landscape change and snow geese in mid-continent North America. Global Change Biology 11:841-855.

Adger, W. N., S. Huq, K. Brown, D. Conway, and M. Hulme. 2003. Adaptation to climate change in the developing world. Progress in Development Studies 3(3):179-195.

Ames, K.M. 2005. Intensification of food production on the Northwest Coast and elsewhere. Pages 67-100 in D. Deur, and N.J. Turner, editors. "Keeping it living": traditions of plant use and cultivation on the Northwest Coast of North America. UBC Press, Vancouver, British Columbia, Canada.

Anderson, K. M. 1996. Tending the wilderness. Restoration and Management Notes 14(2): 154-166.

Andrews, J.T. 1970. Present and postglacial rates of uplift for glaciated northern and eastern North America derived from postglacial uplift curves. Canadian Journal of Earth Sciences 7(1):703-715.

Arctic Climate Impact Assessment (ACIA). 2005. Arctic climate impact assessment. Cambridge University Press, Cambridge, UK.

Armitage, D., F. Berkes and N. Doubleday. 2007. Adaptive co-management: collaboration, learning and multi-level governance. UBC Press, Vancouver, British Columbia, Canada.

Balikci, A. 1968. The Netsilik Eskimos: adaptive processes. Pages 72-82 in R.B. Lee and I. DeVore, editors. Man the hunter. Aldine, Chicago, USA.

Begin, Y., D. Berube, and M. Gregoire. 1993. Downward migration of coastal conifers as a response to recent land emergence in eastern Hudson-Bay, Quebec. Quaternary Research 40 (1):81-88.

Berger, T.R. 1977. Northern frontier northern homeland: the report of the Mackenzie Valley Pipeline Inquiry (Vol. 1). James Lorimer \& Co, Toronto, Ontario, Canada.

Berkes, F. 1995. Indigenous knowledge and resource management systems: a native Canadian case study from James Bay. Pages $99-109$ in S. Hanna and M. Munasinghe, editors. Property rights in a social and ecological context: case studies and design applications. Beijer International Institute of Ecological Economics and the World Bank, Washington, D.C., USA.

Berkes, F., and I. J. Davidson-Hunt. 2006. Biodiversity, traditional management systems, and cultural landscapes: examples from the boreal forest of Canada. International Social Science Journal 58 (1):35-47.

Berkes, F., and C. Folke. 1994. Investing in cultural capital for the sustainable use of natural capital. Pages 128-149 in A.M. Jansson, M. Hammer, C. Folke, and R. Costanza, editors. Investing in natural capital: the ecological economics approach to sustainability, Island Press, Washington, D.C., USA.

Berkes, F., and C. Folke. 1998. Linking social and ecological systems: management practices and social mechanisms for building resilience. Cambridge University Press, Cambridge, UK.

Berkes, F., and D. Jolly. 2001. Adapting to climate change: social-ecological resilience in a Canadian Western Arctic community. Conservation Ecology 5(2):18. [online] URL: http://www.ecologyandsociety. org/vol5/iss2/art18/

Canadian Wildlife Service (CWS). 2005. Canadian Wildlife Service Waterfowl Committee. 
Population status of migratory game birds in Canada (and regulation proposals for overabundant species): November 2005. CWS Migratory Birds Regulatory Report No. 16. CWS, Ottawa.

Cree Nation of Wemindji. 2006. Wemindji Community Profile. Accessed 1 August 2008 [online] URL: http://www.wemindji-nation.qc.ca/c ommunityProfile.pdf

Cree Regional Authority (CRA). 2005. Workshop on migratory birds' data collection in Eeyou Istchee: sharing knowledge. Proceedings of workshop (Wemindji, 2005). [online] URL: http:// www.envcree.ca/communites/documents/

WorkshopReport.pdf

Davidson-Hunt, I.J. 2003. Indigenous lands management, cultural landscapes and Anishinaabe people of Shoal Lake, Northwestern Ontario, Canada. Environments 31(1): 21-42.

Davidson-Hunt, I.J. and F. Berkes. 2001. Changing resource management paradigms, traditional ecological knowledge, and non-timber forest products. Pages 78-92 in Davidson-Hunt, I., Duchesne, L. C., and Zasada, J. C., editors. Forest communities in the thirdmillennium. St Paul: United States Department of Agriculture Forest Service, USA.

Deur, D. 2000. A domesticated landscape: Native American plant cultivation on the Northwest Coast of North America. Dissertation, Department of Geography and Anthropology, Louisiana State University, Louisiana, USA.

Dignard, N., R. Lalumière, A. Reed, and M. Julien. 1991. Habitats of the northeast coast of James Bay. Occasional Paper No. 70. Canadian Wildlife Services, Ottawa.

Dionne, W.H. 1980. An outline of the eastern James Bay coastal environments. Pages 311-388 in S.B. McCann, editor. The coastlines of Canada. Paper 80-10. Geological Survey of Canada, Ottawa.

Ford, J.D., and B. Smit. 2004. A framework for assessing the vulnerability of communities in the Canadian Arctic to risks associated with climate change. Arctic 57(4):389-400.

Ford, J.D., B. Smit, J. Wandel, M. Allurut, K. Shappa, H. Ittusariuats, and K. Qrunnuts. 2008.
Climate change in the Arctic: current and future vulnerability in two Inuit communities in Canada. Geographic Journal 174(1):45-62.

Ford, J.D., B. Smit, J. Wandel, and J. MacDonald. 2006. Vulnerability to climate change in Igloolik, Nunavut: what we can learn from the past and present. Polar Record 42(221):127-138.

Forrest, M. 2006. Stewardship as partnership: a comparative study of positive human-environment relationships in East Cree and suburban Montreal communities. Thesis. McGill University, Department of Geography, Montreal, Quebec, Canada.

Freeman, M. M. R. 1996. Identity, health and social order. Pages 57-71 in M.-L. Foller and L. O. Hansson, editors. Human ecology and health: adaptation to a changing world. Gothenburg University, Gothenburg, Sweden.

German, A. 2009. The Plan du Nord: possibilities and pitfalls. The Nation. 16(5). [online] URL: http: //www.nationnews.ca/index.php?option=com zine\&view= article\&id=39\%3Athe-plan-du-nord-possibilities-andpitfalls\&Itemid $=141$

Grey, J.M. 1983. The measurement of relict shoreline altitudes in areas affected by glacioisostasy, with particular reference to Scotland. Pages 97-127 in D.E. Smith and A.G. Dawson, editors. Shorelines and isostasy. Academic Press, London, UK.

Handa, I.T., R. Harmsen, and R.L. Jefferies. 2002. Patterns of vegetation change and the recovery potential of degraded areas in coastal marsh systems of the Hudson Bay Lowlands. Journal of Ecology 90:86-99.

Harvey, W.F., and J. Rodrigue, 2006. A breeding pair survey of Canada Geese in Northern Quebec, 2006. Maryland Department of Natural Resources, Baltimore, US.

Haas, G. 2002. The Canada Goose: Branta Canadensis Atlantic Flyway resident population. United States Fish and Wildlife Service, Migratory Birds. Hadley, Massachusetts, USA.

Hassol, S.J. 2004. Impacts of a warming Arctic: Arctic climate impact assessment. University Press, Cambridge, UK. 
Hik, D.S., R.L. Jefferies, and A.R.E. Sinclair. 1992. Foraging by geese, isostatic uplift and asymmetry in the development of salt-marsh plant communities. Journal of Ecology 80(3):395-406.

Hillaire-Marcel, C. 1980. Multiple component postglacial emergence, eastern Hudson Bay, Canada. Pages 215-230 in N.A. Morner, editor. Earth rheology, isostasy and eustasy. John Wiley and Sons, Toronto, Ontario, Canada.

Hulan, R. 2003. Northern experience and the myths of Canadian culture. McGill-Queens University Press. Montreal, Quebec, Canada.

Huntington, H., and S. Fox. 2005. The changing Arctic: indigenous perspectives. Pages 61-98 in C. Symon, L. Arris, and B. Heal, editors. Arctic climate impact assessment. Cambridge University Press, Cambridge, UK.

Krupnik, I., and D. Jolly. 2002. The earth is faster now: indigenous observations of Arctic environmental change. Arctic Research Consortium of the United States, Fairbanks, Alaska, USA.

Lajeunesse, P. and M. Allard. 2003. Late Quaternary deglaciation, glaciomarine sedimentation and glacioisostatic recovery in the Rivière Nastapoka Area, Eastern Hudson Bay, Northern Québec. Géographie Physique et Quaternaire 57 (1):65-83.

Langdon, S. J. 1995. Increments, ranges and thresholds: human population responses to climate change in northern Alaska. Pages 139-154 in D. L. Peterson and D. R. Johnson, editors. Human ecology and climate change: people and resources in the far north. Taylor and Francis, Washington, D.C., USA.

Lewis, H. T., and Ferguson, T. A. 1988. Yards, corridors, and mosaics: how to burn a boreal forest. Human Ecology 16(1):57-77.

Natcher, D.C., O. Huntington, S. Trainor, H.P. Huntington, L. DeWild, S. Rupp, F.S., and M. Chapin III. 2007. Factors contributing to the cultural and spatial variability of landscape burning by native peoples of Interior Alaska. Ecology and Society 12(1):7 [online] URL: http://www.ecologya ndsociety.org/vol12/iss1/art7/.
Nelson, D.R., W.N. Adger, and K. Brown. 2007. Adaptation to environmental change: contributions of a resilience framework. Annual Review of Environment and Resources. 32:395-419.

Nickels, S., C. Furgal, J. Castleden, P. MossDavies, M. Buell, B. Armstrong, D. Dillion, and R. Forger 2002. Putting the human face on climate change through community workshops: Inuit knowledge, partnerships, and research. Pages 300 344 in I. Krupnik and D. Jolly, editors. The earth is faster now: indigenous observations of Arctic environmental change. Arctic Research Consortium of the United States, Arctic Studies Centre, Smithsonian Institute, Washington, D.C., USA.

Overpeck, J., K. Hughen, D. Hardy, R. Bradley, R. Case, M. Douglas, B. Finney, K. Gajewski, G. Jacoby, A. Jennings, S. Lamoureux, A. Lasca, G. MacDonald, J. Moore, M. Retelle, S. Smith, A. Wolfe, and G. Zielinski. 1997. Arctic environmental change of the last four centuries. Science 278(5341):1251-1256.

Parlee, B., F. Berkes, and Teetl'it Gwich'in Renewable Resource Council. 2005. Health of the land, health of the people: a case study on berry harvesting from northern Canada. EcoHealth. 2 (2):127-137.

Peacock, S.L. 1998. Putting down roots: the emergence of wild plant food production on the Canadian plateau. Dissertation. University of Victoria, Victoria, British Columbia, Canada.

Peacock, S. L., and N. J. Turner. 2000. "Just like a garden": traditional resource management and biodiversity conservation on the Interior Plateau of British Columbia. Pages 133-179 in P. Minnies and W. Elisens, editors. Biodiversity and native North America. University of Oklahoma Press, Norman, Oklahoma, USA.

Pearce, T.D., B. Smith, F. Dearden, F. Kataoyak, A. Goose, R. Inuktalik, J. Ford, and J. Wandel. 2006. Travel routes, harvesting and climate change in Uluhaktok, Canada. Pages 148-155 in J.H. Ingimundarson, E.E. Oddsdóttir, and G.R. P\&\#243rsteindóttr, editors. Proceedings of the 4th Northern Research Forum Open Meeting - the 
borderless North. Oulu, Finland and Lulea, Sweden. [online] URL: http://www.nrf.is/Publications/The\% 20Borderless\%20North/Borderless\%20North.htm

Peloquin, C., and F. Berkes. 2009. Local knowledge, subsistence harvesting, and socialecological complexity in James Bay. Human Ecology. 37(5):533-545.

Reed, A.J. 1991. Subsistence harvesting of waterfowl in northern Quebec: goose hunting and the James Bay Cree. Pages 344-349 in R.E. McCabe, editor. Transactions of the $56^{\text {th }}$ North American Wildlife and Natural Resource Conference. Wildlife Management Institute, Washington, D.C., USA.

Reed, A., R. Benoit, R. Lalumière, and M. Julien. 1996. Goose use of the coastal habitats of northeastern James Bay. Canadian Wildlife Service, Environment Canada, Ottawa, Ontario, Canada.

Resilience Alliance. 2001. [online] URL: http://ww w.resalliance.org/576.php

Riedlinger, D. and F. Berkes. 2001. Contributions of traditional knowledge to understanding climate change in the Canadian Arctic. Polar Record 37:315-328.

Rogers, E.S. 1983. Cultural adaptations: the northern Ojibwa of the boreal forest 1670-1980. Pages 85-142 in A.T. Steegmann, Jr., editor. Boreal forest adaptations: the Northern Algonkians. Plenum Press, New York, New York, USA.

Sandlos, J. 2007. Hunters at the margin: native people and wildlife conservation in the Northwest Territories. UBC Press, Vancouver, British Colombia, Canada.

Sayles, J.S. 2008. Tapaiitam: Human modifications of the coast as adaptations to environmental change, Wemindji, Eastern James Bay. Thesis. Department of Geography, Planning and Environment, Concordia University. Montreal, Quebec, Canada.

Scott, C.H. 1983. The semiotics of material life among Wemindji Cree hunters. Dissertation. McGill University, Montreal, Quebec, Canada.
Scott, C.H. 1986. Hunting territories, hunting bosses and communal production among coastal James Bay Cree. Anthropologica 28(1-2):163-173.

Scott, C.H. 1988. Property, practice and aboriginal rights among Quebec Cree hunters. Pages 35-51 in T. Ingold, D. Riches and J. Woodburn, editors. Hunters and gatherers, Vol. 2 property, power and ideology. Berg Publishers Limited, Oxford, UK.

Scott, C.H. 1996. Science for the west, myth for the rest? The case of James Bay Cree knowledge construction. Pages 69-86 in L. Nader, editor. Naked science: anthropology inquiry into boundaries, power, and knowledge. Routledge, London, UK.

Societe des Travaux de correction du Complexe la Grande (SOTRAC). 1980. Annual Report 1980. SOTRAC, Montreal, Quebec, Canada.

Steegman, Jr. A.T., M.G. Hurlich, and B. Winterhalder. 1983. Coping with cold and other challenges of the boreal forest: an overview. Pages 317-351 in A.T. Steegmann, Jr., editor. Boreal forest adaptations: the Northern Algonkians. Plenum Press, New York, New York, USA.

Stewart, H. 1977. Indian fishing: early methods on the Northwest Coast. Douglas \& McIntyre, Vancouver, British Colombia, Canada.

Turner, N.J. 1999 Time to burn: traditional use of fire to enhance resource production by Aboriginal Peoples in British Columbia. Pages 185-218 in Boyd, R., editor. Indians, fire and the land in the Pacific Northwest. Oregon State University Press, Corvallis, USA.

Turner, N.J., and H. Clifton. 2009. "It's so different today": Climate change and indigenous lifeways in British Columbia, Canada. Global Environmental Change 19:180-190.

Turner, N.J., I.J. Davidson-Hunt, and M. O'Flaherty. 2003. Living on the edge: ecological and cultural edges as sources of diversity for socialecological resilience. Human Ecology 31 (3):439-461.

Turner, N. J., M. B. Ignace, and R. Ignace. 2000. Traditional ecological knowledge and wisdom of aboriginal peoples in British Columbia. Ecological Applications 10(5):1275-1287. 
Turner, N. J., and S. Peacock. 2005. Solving the perennial paradox: Traditional plant management on the Northwest Coast. Pages 95-127 in D. Deur, and N.J. Turner, editors. "Keeping it living:" indigenous plant management on the Northwest Coast. University of Washington Press, Seattle, USA.

van Moris, I., and Y. Begin. 1993. Shoreline shrub population extension in response to recent isostatic rebound in eastern Hudson Bay, Quebec, Canada. Arctic and Alpine Research 25(1):15-23. 